\title{
Productivity, profitability and water use efficiency of wheat (Triticum aestivum L.) under different customized fertilizers and moisture regimes
}

\author{
Dheeraj K. Tiwari ${ }^{1 *}$, G. R. Singh ${ }^{1}$, S. P. Singh ${ }^{2}$, S. K. Pandey ${ }^{3}$ and V. D. Yadav \\ ${ }^{1}$ Department of Agronomy, Narendra Deva University of Agriculture \& Technology Kumarganj, Faizabad -224229 \\ (U. P.), INDIA \\ ${ }^{2}$ Research and Development Division, Indogulf Fertilizers Ltd. Jagdishpur-227817 (U. P.), INDIA \\ ${ }^{3}$ Krishi Vigyan Kendra, Chandauli- 232104 (U. P.), INDIA \\ ${ }^{4}$ Department of Agronomy, SVBPUAT, Meerut- 250110 (U. P.), INDIA \\ *Corresponding author. E-mail: dk9hau@gmail.com \\ Received: May 6, 2015; Revised received: February 14, 2016; Accepted: April 17, 2016
}

\begin{abstract}
A field experiment was conduct during the winter (rabi) season of 2010-2011 on silty loam soil at Faizabad (Uttar Pradesh), India to develop suitable dose of customized fertilizers (CF) and moisture regime for wheat (Triticum aestivum L.) crop. Productivity of grain and straw of wheat increased with increasing level of nutrient. Highest grain yield (53.13 q ha-1) was recorded under the application of CF $12: 30: 16: 0.5: 0: 5$ (NPK $150: 75: 40$ ) which was accounted increases of $18.22 \%, 14.55 \%$ and $10.88 \%$ more yield than F1, F4 and F6 treatment respectively. Highest water use efficiency was recorded with $6 \mathrm{~cm}$ irrigation at 0.8 IW/CPE ratio and customize fertilizer 12: 30: 16: 0.5: 0: 5(NPK 150: 75: 40). The highest net returns (Rs. 61324 ha $^{-1}$ ) and B:C (2.29) were recorded under the treatment combination of 1.0 IW/CPE ratio + customize fertilizer 12: 30: 16: 0.5: 0: 5 (NPK 150: 75: 40). The increased dose of fertilization in the form of CF with proper irrigation scheduling in wheat has a high scope for the maximization of yield as well as profitability in wheat growing regions of Uttar Pradesh.
\end{abstract}

Keywords: Customized fertilizer, IW/CPE ratio, Water use efficiency, Wheat, Yield attributes

\section{INTRODUCTION}

Wheat (Triticum aestivum L.) is one of the most important cereal crops of the world. In India, wheat is the second most important cereal crop after rice grown under sub-tropical environment during November to April, covering an area of 30.21 million ha. Total annual production of wheat in India is 94.88 million tonnes, with the productivity of 3.14 tonnes/ha (DES, 2014). The productivity of wheat in Uttar Pradesh is very low (2.5 tonnes/ha) which might be due to the adoption of cereal-cereal (rice-wheat) cropping system, imbalance fertilization, poor water management, late sowing and poor weed management, etc. Irrigation in wheat cultivation is one of the most important factors as during the growing season of the crop weather remains relatively dry, except a few light showers which may be achieved occasionally (Lenka et al., 2009). Thus, irrigation in wheat cultivation is quite essential to lead not only to increased yields per unit of land area and time but also to alleviate the economic condition of the farmers. The balance nutrition plays an important role in raising the production potential of high yielding varieties of wheat which have been found highly responsible to nitrogen, phosphorus and potassium and as well as micro nutrients e.g. zinc, sulphur and boron. The efficiency of both nitrogen and phosphorus is greatly enhanced with the application in combination of potasic fertilizer and further improves the utilization of nitrogen and phosphorus. The soils of U.P. are deficient in micronutrients of zinc, sulphur and boron (Singh et al., 2007). The application of N, P, $\mathrm{K}, \mathrm{Zn}$ and $\mathrm{S}$ containing fertilizers in proper proportion is necessary to augment the productivity of wheat. Irrigation and nutrient management $(\mathrm{N}, \mathrm{P}, \mathrm{K}, \mathrm{S}, \mathrm{Zn}$ and $\mathrm{B})$ play a vital role in growth and development vis-a-vis grain and straw yields. Hence, the effect of various fertilizers in balanced proportion on yield of wheat will be of immense significance to understand the fertilizer requirement, because they reach their full yield potential with adequate supply of various fertilizers (Bhuvaneswary et al., 2007). Therefore, the application of adequate irrigation and fertilizers in balanced proportion is necessary for the highest possible yield. The application of more number of fertilizers to supply the different nutrients are not economically feasible as well as impractical for farming community, It will be easy to apply and feasible on economic point of view when crop is fertilized with one source for all essential nutrients. In view of the above facts, the present investigation entitled "Effect of irrigation and customized fertilizers on the performance of wheat (Triticum aestivum L.) was carried out during 2010-11 at Faizabad, Uttar Pradesh. 


\section{MATERIALS AND METHODS}

A field experiment was conducted site during the winter season of 2010-11 at the Agronomy Research Farm, of N.D. University of Agriculture of and Technology, Narendra Nagar, (24.40-26.60 N, 82.10$83.90 \mathrm{E}$, with an altitude $113 \mathrm{~m}$ above mean sea level) Faizabad, India. Climate is warm humid subtropical with cool, dry winters from November to February; Average annual rainfall is $1200 \mathrm{~mm}$ and about $90 \%$ which is contributed by south west monsoon from June to September. Soil of experimental field was silt loam with $\mathrm{pH}$ of 7.9, Electric Conductivity (EC) $0.25 \mathrm{dSm}^{-1}$, low in organic C $(0.37 \%)$, available $\mathrm{N}\left(180 \mathrm{kgha}^{-1}\right)$, medium in available $\mathrm{P}\left(14.3 \mathrm{kgha}^{-1}\right)$ and $\mathrm{K}(210$ $\left.\mathrm{kgha}^{-1}\right)$. A range of mean minimum and maximum temperatures during the crop season ranged from 2.5 ${ }^{0} \mathrm{C}$ to $25.2{ }^{\circ} \mathrm{C}$ and $14.3{ }^{\circ} \mathrm{C}$ to $39.2{ }^{\circ} \mathrm{C}$, respectively. The total rainfall received was $15.3 \mathrm{~mm}$ during the entire crop season. The relative humidity, evaporation rate and sun shine hours were found to vary from 36.5 to 85.7 per cent, 10.1 to $33.5 \mathrm{~mm} \mathrm{day}^{-1}$ and 1.4 to 8.7 hours, respectively. The experiment was carried out in randomized block design (RBD) with three replications, and consists of following treatments presented in table 1.

After harvesting of rainy-season crops, the experimental field was prepared giving a pre-sowing irrigation and ploughing with tractor drawn soil turning plough followed by crossed harrowing and planking to bring the soil in good tilth. According to treatments, application of fertilizers through Urea, Di Ammonium Phosphate, Muriate of Potash, Zinc, Borax and Bentonite Sulphur was given out. Half dose of nitrogen and full dose of other fertilizers were applied as basal dressing. Remaining half dose of nitrogen through urea was top dressed in two equal doses. The sowing of crop was done in rows, at $20 \mathrm{~cm}$ apart at $4-5 \mathrm{~cm}$ deep by hand. Irrigation was scheduled on the basis of IW/CPE ratio. Weeds were controlled with Sulfosulfuron herbicide @ $25 \mathrm{gm}$ a.i. $\mathrm{ha}^{-1}$ as post-emergence application after 30 DAS. The other recommended package of practices was dully followed. The crop was evaluated in terms of yield attributes (Effective tillers $/ \mathrm{m}^{2}$, Length of spike, grains/spike, Grain weight/spike, 1000- grain weight, Grain yield, Straw yield and Harvest index), gross returns, net returns, benefit cost ratios, consumptive use of water and water use efficiency. Data on plant growth attributes were recorded at 30,6090 day after sowing (DAS) and at harvest stage and yield attributes were recorded at crop maturity. Standard procedures were used for chemical analysis of soil and plant sample. Data collected during the study were statistically analyzed by using the technique of analysis of variance (ANOVA) described by (Panse \& Sukhatme 1978). To judge the significant difference between means of two treatments, the critical difference (C.D.) was worked out using following formula, cited in Cochran \& Cox (1959).

Table 1. Details of treatments used in experiments.

\begin{tabular}{lll}
\hline A. & Irrigation schedule & Symbol used \\
\hline i. & $6 \mathrm{~cm}$ irrigation at 0.8 IW/CPE ratio & $\mathrm{I}_{1}$ \\
ii. & $6 \mathrm{~cm}$ irrigation at 1.0 IW/CPE ratio & $\mathrm{I}_{2}$ \\
\hline B. & Customized fertilizers & Symbol used \\
\hline i. & ICAR Application NPK Zn B S $120: 60: 40: 2: 0: 8$ & $\mathrm{~F}_{1}$ \\
ii. & Customize fertilizer $12: 30: 16: 0.5: 0: 5$ (NPK $150: 75: 40)$ & $\mathrm{F}_{2}$ \\
iii. & Customize fertilizer $12: 26: 18: 0.5: 0: 5$ (NPK $150: 65: 45)$ & $\mathrm{F}_{3}$ \\
iv. & Customize fertilizer $10: 20: 24: 0.5: 0.01: 5$ (NPK $150: 50: 60)$ & $\mathrm{F}_{4}$ \\
v. & Customize fertilizer $15: 30: 20: 2: 0: 8$ (NPK $150: 75: 50)$ & $\mathrm{F}_{5}$ \\
vi & Customize fertilizer $10: 18: 25: 0.5: 0: 3$ (NPK $120: 45: 62.5)$ & $\mathrm{F}_{6}$ \\
\hline
\end{tabular}

Table 2. Effective tillers, length of spike, number of grains per spike, grain weight per spike, grain yield, straw yield and harvest indexof wheat as influenced by moisture regimes and customized fertilizers.

\begin{tabular}{|c|c|c|c|c|c|c|c|c|}
\hline Treatments & $\begin{array}{l}\text { Effective } \\
\text { tillers }\left(\mathrm{m}^{2}\right)\end{array}$ & $\begin{array}{l}\text { Length of } \\
\text { spike }(\mathrm{cm})\end{array}$ & $\begin{array}{l}\text { Number of } \\
\text { grains per } \\
\text { spike }\end{array}$ & $\begin{array}{l}\text { Grain } \\
\text { weight per } \\
\text { spike (g) }\end{array}$ & $\begin{array}{l}1000- \\
\text { grain } \\
\text { weight (g) }\end{array}$ & $\begin{array}{l}\text { Grain } \\
\text { yield } \\
\left(\mathrm{q} \mathrm{ha}^{-1}\right)\end{array}$ & $\begin{array}{l}\text { Straw } \\
\text { yield } \\
\left(\mathrm{q} \mathrm{ha}^{-1}\right)\end{array}$ & $\begin{array}{l}\text { Harvest } \\
\text { index }(\%)\end{array}$ \\
\hline \multicolumn{9}{|c|}{ Moisture regimes } \\
\hline $\mathrm{I}_{1}$ & 331.30 & 7.83 & 33.61 & 1.11 & 39.11 & 46.38 & 56.56 & 45.09 \\
\hline $\mathrm{I}_{2}$ & 358.90 & 8.47 & 36.57 & 1.20 & 39.14 & 50.23 & 59.63 & 45.08 \\
\hline $\mathrm{SEm} \pm$ & 6.68 & 0.14 & 0.65 & 0.02 & 0.30 & 0.97 & 0.88 & 0.62 \\
\hline $\mathrm{CD}$ at $5 \%$ & 19.60 & 0.41 & 1.91 & 0.07 & NS & 2.87 & 2.59 & NS \\
\hline \multicolumn{9}{|c|}{ Customized fertilizers } \\
\hline$\overline{F_{1}}$ & 310.60 & 7.33 & 31.50 & 1.03 & 37.35 & 43.45 & 52.22 & 45.37 \\
\hline $\mathrm{F}_{2}$ & 379.60 & 8.95 & 38.50 & 1.26 & 41.15 & 53.13 & 64.80 & 45.04 \\
\hline $\mathrm{F}_{3}$ & 365.80 & 8.65 & 37.10 & 1.22 & 40.74 & 51.23 & 62.48 & 45.04 \\
\hline $\mathrm{F}_{4}$ & 324.40 & 7.65 & 32.90 & 1.10 & 38.18 & 45.40 & 55.40 & 44.96 \\
\hline $\mathrm{F}_{5}$ & 352.00 & 8.33 & 35.70 & 1.19 & 39.67 & 49.28 & 60.10 & 45.18 \\
\hline $\mathrm{F}_{6}$ & 338.20 & 7.98 & 34.83 & 1.14 & 37.66 & 47.35 & 57.75 & 44.93 \\
\hline $\mathrm{SEm} \pm$ & 11.57 & 0.24 & 1.12 & 0.04 & 0.52 & 1.69 & 1.50 & 1.07 \\
\hline $\mathrm{CD}$ at $5 \%$ & 33.95 & 0.72 & 3.30 & 0.12 & 1.52 & 4.97 & 4.41 & NS \\
\hline
\end{tabular}


Table 3. Water use efficiency, cost of cultivation, gross return, net return and benefit cost ratio as influenced by moisture regimes and customized fertilizers.

\begin{tabular}{|c|c|c|c|c|c|}
\hline Treatments & $\begin{array}{c}\begin{array}{c}\text { Water use efficiency } \\
\left(\mathrm{kg} \mathrm{ha}^{-1} \mathrm{~cm}^{-1}\right)\end{array} \\
\end{array}$ & $\begin{array}{c}\text { Cost of cultivation } \\
\left(\text { Rs.ha }^{-1}\right)\end{array}$ & $\begin{array}{c}\left.\begin{array}{c}\text { Gross return } \\
(\text { Rs. ha }\end{array}{ }^{-1}\right) \\
\end{array}$ & $\begin{array}{c}\text { Net return } \\
\left(\text { Rs. ha }{ }^{-1}\right)\end{array}$ & $\begin{array}{c}\text { Benefit cost } \\
\text { ratio }\end{array}$ \\
\hline$\overline{\mathrm{I}_{1}}$ & 147.08 & 23718 & 67980 & 44261 & 1.86 \\
\hline $\mathrm{I}_{2}$ & 133.84 & 24368 & 73146 & 48777 & 1.99 \\
\hline $\mathrm{SEm} \pm$ & 0.81 & --- & --- & 298 & 0.02 \\
\hline $\mathrm{CD}$ at $5 \%$ & 2.42 & --- & --- & 852 & 0.05 \\
\hline \multicolumn{6}{|c|}{ Customized fertilizers } \\
\hline $\mathrm{F}_{1}$ & 126.34 & 23891 & 62210 & 38319 & 1.60 \\
\hline $\mathrm{F}_{2}$ & 154.48 & 24271 & 77877 & 53606 & 2.20 \\
\hline $\mathrm{F}_{3}$ & 148.96 & 24094 & 75090 & 50996 & 2.11 \\
\hline $\mathrm{F}_{4}$ & 132.02 & 24001 & 66560 & 42559 & 1.77 \\
\hline $\mathrm{F}_{5}$ & 143.28 & 24735 & 72232 & 47495 & 1.91 \\
\hline $\mathrm{F}_{6}$ & 137.70 & 23270 & 69410 & 46140 & 1.98 \\
\hline SEm \pm & 1.52 & --- & --- & 365 & 0.05 \\
\hline $\mathrm{CD}$ at $5 \%$ & 4.55 & --- & --- & 1044 & 0.16 \\
\hline
\end{tabular}

\section{RESULTS AND DISCUSSION}

Yield attributes: A perusal of data shows that various irrigation schedules affect the number of spike $\mathrm{m}^{-1}$ was recorded under 1.0 IW/CPE ratio, which was significantly higher than $0.8 \mathrm{IW} / \mathrm{CPE}$ ratio. The differences in number of spike $\mathrm{m}^{-1}$ due to successive level of $\mathrm{CF}$ were significant at $\mathrm{F}_{2}$. However, the maximum number of spike running $\mathrm{m}^{-1}$ was recorded under $\mathrm{F}_{2}$ treatment which was significantly better than $F_{1}, F_{4}$ and $F_{6}$ treatment. Significantly higher spike length was obtained under $1.0 \mathrm{IW} / \mathrm{CPE}$ ratio than $0.8 \mathrm{IW} / \mathrm{CPE}$ ratios (Ghanbari et. al. 2011). The differences in length of spike due to customized fertilizers level was significant at $\mathrm{F}_{2}$ with $\mathrm{F}_{1}, \mathrm{~F}_{4}$ and $\mathrm{F}_{6}$ treatment and at par with $\mathrm{F}_{3}$ and $\mathrm{F}_{5}$ treatment. The maximum number of grains per spike (36.57) was recorded under 1.0 IW/CPE ratio and was found significantly better over $0.8 \mathrm{IW} / \mathrm{CPE}$ ratios. Increasing dose of nutrient in customized fertilizers increased the number of grains per spike significantly (Jat et. al. 2013). The crop fertilized with $\mathrm{F}_{2} \mathrm{FC}$ $12: 30: 16: 0.5: 0: 5$ (NPK $150: 75: 40)$ produced significantly higher number of grains per spike (38.50) which was found significantly more over $F_{1}, F_{4}$ and $\mathrm{F}_{6}$ treatments. Maximum grain weight per spike (g) was recorded under 1.0 IW/CPE ratio, which was significantly more than $0.8 \mathrm{IW} / \mathrm{CPE}$ ratio treatments. The maximum grain weight per spike (g) was recorded under $F_{2} C F$ which was significantly better than $F_{1}, F_{4}$ and $\mathrm{F}_{6}$ treatments. The difference in 1000 -grain weight (g) due to moisture regime were found non significant. An examination of data indicates that maximum 1000grain weight $(41.15 \mathrm{~g})$ was obtained under $\mathrm{F}_{2} \mathrm{CF}$ which was significantly better than $\mathrm{F}_{1}, \mathrm{~F}_{4}$ and $\mathrm{F}_{6}$ treatments and at par with $\mathrm{F}_{3}$ and $\mathrm{F}_{5} \mathrm{CF}$ treatments (Singh and Singh 2009). An examination of data clarifies that maximum grain yield $\left(50.23 \mathrm{qha}^{-1}\right)$ was obtained under $1.0 \mathrm{IW} / \mathrm{CPE}$ ratio, which was significantly superior over $0.8 \mathrm{IW} / \mathrm{CPE}$ treatments. Grain yield under 1.0 IW/CPE was recorded in the tune of $8.30 \%$ more than $0.8 \mathrm{IW} / \mathrm{CPE}$ ratio. Different customized fertilizer level influenced the grain yield of wheat significantly. It increased significantly on $\mathrm{F}_{2} \mathrm{CF}$ treatment. The maximum grain yield was obtained under $F_{2}$ treatment, which was found significantly better than $F_{1}, F 4$ and $F_{6}$ treatments. The maximum straw yield was noticed under 1.0 IW/CPE ratio, which was significantly higher than 0.8 IW/CPE ratios. Straw yield (59.63 qha ${ }^{1}$ ) under 1.0 IW/CPE ratio was recorded at the tune of $5.15 \%$ more than $0.8 \mathrm{IW} / \mathrm{CPE}$ ratios. Customized fertilizers had significant effect for straw yield of wheat, it increased significantly with $\mathrm{F}_{2} \mathrm{CF}$ treatment. The highest straw yield of $64.80 \mathrm{qha}^{-1}$ was found with $\mathrm{F}_{2}$ $\mathrm{CF}$ treatment. The yield attributes viz. number of spike per running meter, length of spike $(\mathrm{cm})$, no. of grains per spike, grain weight per spike (g) and 1000- grain weight $(\mathrm{g})$ increased with increasing dose of nutrient upto CF $12: 30: 16: 0.5: 0: 5$ (NPK $150: 75: 40$ ). Application of customize fertilizer increased the dry matter accumulation in assimilation organs that in term brought about increase yield attributes (Sharma et. al. 2007 and Srinivasa et. al. 2010). Grain and straw yield increased with increasing level of nutrient. Highest grain yield $\left(53.13 \mathrm{q} \mathrm{ha}^{-1}\right)$ was recorded under the application of CF $12: 30: 16: 0.5: 0: 5$ (NPK $150: 75$ : 40) accounted increases of $18.22 \%, 14.55 \%$ and $10.88 \%$ more than F1, F4 and F6 treatment respectively.

Economics: The variation in cost of cultivation were recorded due to moisture regime, customized fertilizers, which was increased with increasing level of nutrient in customized fertilizers, irrigation and nutrients are the major monitory inputs. Grain yield was major factor, which caused differences in net income and net return per rupee invested (Lenka et. al. 2009). Maximum cost of cultivation was recorded under the moisture regime of $1.0 \mathrm{IW} / \mathrm{CPE}$ ratio + CF $15: 30: 20: 2$ : $0: 8$ (NPK $150: 75: 50$ ) while minimum (Rs. 22945 $\mathrm{ha}^{-1}$ ) under treatment combination of $0.8 \mathrm{IW} / \mathrm{CPE}+$ CF $10: 18: 25: 0.5: 0: 3$ (NPK 120:45:62.5). Maximum gross return (Rs. $80995 \mathrm{ha}^{-1}$ ) was recorded under the treatment combination of $1.0 \mathrm{IW} / \mathrm{CPE}$ ratio + CF $12: 30: 16: 0.5: 0: 5$ (NPK $150: 75: 40$ ). Highest net return (Rs. $61324 \mathrm{ha}^{-1}$ ) was recorded under 1.0 
IW/CPE ratio + CF $12: 30: 16: 0.5: 0: 5$ (NPK $150:$ $75: 40)$ and highest benefit : cost ratio (2.29) were recorded under the treatment combination of $1.0 \mathrm{IW} /$ CPE ratio + CF $12: 30: 16: 0.5: 0: 5$ (NPK 150: $75: 40$ ) (Sharma et. al. 2007).

Water use efficiency (WUE): Water use efficiency (WUE) markedly influenced by different moisture regime. The highest water use efficiency $\left(147.08 \mathrm{kgha}^{-}\right.$ ${ }^{1} \mathrm{~cm}^{-1}$ ) was recorded under irrigation applied at $0.8 \mathrm{IW} /$ CPE ratio followed by moisture regime 1.0 IW/CPE ratio. The consumptive use of water (CU) and water use efficiency (WUE) increasing with increasing nutrient proportion upto customize fertilizer $12: 30: 16$ : $0.5: 0: 5$ (NPK $150: 75: 40$ ). Application of more nitrogen favoured the growth of plants, as they consumed more amount of water for their metabolic processes and transpiration which in term led to higher consumptive use (Chen et. al. 2014). The increase in water use efficiency with increasing nutrient level was mainly due to proportionately higher increase in grain yield than consumption of water.

\section{Conclusion}

On the basis of experimental findings, it may concluded that planting of wheat under irrigation $1.0 \mathrm{IW} /$ CPE ratio and customized fertilizer NPK ZnB S (12: $30: 16: 0.5: 0: 5)$ (NPK $150: 75: 40$ ) was found better with respect to growth yield attributing character, yield and economics while irrigation at $0.8 \mathrm{IW} /$ CPE ratio and customize fertilizer NPK ZnB S (12: $30: 16: 0.5: 0: 5)$ (NPK $150: 75: 40$ ) was better in relation to water use efficiency $\left(150.78 \mathrm{~kg} \mathrm{ha}^{-1} \mathrm{~cm}^{-1}\right)$. The highest profitability (net returns Rs. $61324 \mathrm{ha}^{-1}$ and $B: C$ 2.29) of wheat was computed under the treatment combination of 1.0 IW/CPE ratio + customize fertilizer NPK ZnB S $(12: 30: 16: 0.5: 0: 5)$ (NPK $150: 75: 40$ ). The increased dose of fertilization (both macro and micro nutrients) in the form of $\mathrm{CF}$ with proper irrigation scheduling in wheat has a high scope for the maximization of yield as well as profitability in wheat growing regions of Uttar Pradesh.

\section{REFERENCES}

Bhuvaneswary, R., Srivamchandra, S.M.V. and Ravichandran, M. (2007). Effect of organic and grated level of sulphur on wheat yield and sulphur use efficiency. $J$. of Interacad. 11 (1): 51-54.

Chen, S., Sun, H., Shao, L. and Zhang, X. (2014). Performance of winter wheat under different irrigation regimes associated with weather conditions in the North China Plain. Aust. J. of crop sci. 8 (4): 550-557.

Cochran, W.G. and Cox, G.M. (1959). Experimental Designs, John Willey Pub., New York.

DES. (2014). Area, production and productivity of crops. Agricultural Statistics at a Glance. Directorate of Economics and Statistics, DAC, GOI, pp.105.

Ghanbari, M., Malidarreh, A., Rajabi-Vandechali, M., Ebadi, A. and Dastan, S. (2011). The effect of complementary irrigation in growth stages on yield, qualitative and quantitative indices of wheat (Triticum aestivum L.). American-Eurasian J. of Agri. and Environ. Sci. 11 (3): 320-325.

Jat, G., Majumdar, S.P., Jat, N.K. and Majumdar, Sonali P. (2013). Potassium and zinc fertilization of wheat (Triticum aestivum) in western arid zone of India. Indian J. of Agron. 58 (1): 67-71.

Lenka, S., Singh, A.K. and Lenka, N. (2009). Water and nitrogen interaction on soil profile water extraction and ET in maize-wheat cropping system. Agri. Water Manage. 96: 195-07.

Panse, V.G. and Sukhatme, P.R. (1978). Statistical Methods for Agricultural Workers. ICAR, New Delhi.

Sharma, A., Singh, H. and Nanwal, R.K. (2007). Effect of integrated nutrient management on productivity of wheat (Triticum aestivum) under limited and adequate irrigation supplies. Indian J. of Agron. 52(2): 120-123.

Srinivasa, R.C., Subbarao, A., Rao, K.V., Venkataseswarlu, B. and Singh, A.K. (2010). Categorization of districts based on non exchangeable potassium and Implications in efficient $\mathrm{K}$ fertility management in Indian Agriculture. Indian J of Ferti. 6: 40-54.

Singh, J.P. and Singh, V. (2009). Response of rabi crops to potassium. Better C. India 3 (1): 16-17.

Singh, R.K., Singh, S.K. and Singh, L.B. (2007). Integrated nitrogen management in wheat (Triticum aestivum). Indian J of Agron. 52(2): 124-127. 